\title{
INVENTARISASI HAMA KELAPA SAWIT ( Elaeis guineensis Jacq.) PADA DAERAH ENDEMIK SERANGAN DI KABUPATEN DHARMASRAYA
}

\author{
Febriani $^{1}$, Yusniwati ${ }^{2}$, Siska Efendi $^{1}{ }^{*}$ \\ ${ }^{1)}$ Program Studi Agroekoteknologi, Jurusan Budidaya Perkebunan, Fakultas Pertanian, \\ Kampus III Universitas Andalas Dharmasraya. Jl. Lintas Sumatera Km 4 Pulau Punjung, \\ Dharmasraya (27612), Indonesia \\ ${ }^{2)}$ Program Studi Agroteknologi, Jurusan Budidaya Pertanian, Fakultas Pertanian, \\ Universitas Andalas, Limau Manis, Padang (25163), Indonesia \\ *email koresponden: siskaefendi@agr.unand.ac.id
}

\begin{abstract}
ABSTRAK
Inventarisasi Hama Kelapa Sawit ( Elaeis Guineensis Jacq.) Pada Daerah Endemik Serangan

Di Kabupaten Dharmasraya. Suatu daerah dikatakan endemik apabila terdapat laporan serangan OPT tertentu dalam skala besar. Daerah endemik serangan hama kelapa sawit dapat menjadi pedoman dalam mempelajari tingkat serangan hama di daerah tertentu. Ketinggian serangan hama pada daerah tertentu dapat menjadi acuan dalam menentukan teknik pengendalian yang tepat. Penelitian ini bertujuan untuk mengetahui jenis hama yang menyerang tanaman kelapa sawit di daerah endemik Kabupaten Dharmasraya. Metode yang digunakan adalah purposive random sampling. Sedangkan untuk pengambilan sampel dilakukan dengan koleksi langsung menggunakan tangan. Hasil penelitian ini didapatkan sebanyak 353 individu serangga dari 4 ordo, 9 famili dan 14 spesies. Jumlah individu tertinggi berasal dari Coptotermes sp sedangkan yang terendah spesies Setora nitens. Berdasarkan hasil penelitian dapat disimpulkan bahwa keanekaragaman serangga endemik kelapa sawit menyerang sangat tinggi dengan total spesies yang ditemukan sebanyak 14 spesies.
\end{abstract}

Kata kunci : CPO, Lepitoptera, Musuh Alami, Penyakit, Pestisida.

\begin{abstract}
Inventory Of Oil Palm ( Elaeis guineensis Jacq.) Pests In Endemic Areas Of Dharmasraya. An area is considered endemic if there are reports of attacks by a particular pest on a large scale.Endemic areas of oil palm pest attack can be a benchmark for studying the level of pest attack in a particular area. The level of attack in a particular area can be a reference for determining appropriate control techniques. This research aimed to identify the types of pest which attack oil palm crops in endemic areas Dharmasraya. Purposif random sampling was used.Three hundred and fifty three individual insects belonging to4 orders, 9 families dan 14 species were collected. The highest number of individuals was from Coptotermeswhile the lowest number of individuals was recorded forSetora nitens.It was concluded that the diversity of insects in oil palm endemik areasis high.
\end{abstract}

Key words : CPO, Diseases, Lepitoptera, Natural Enemies, Pesticides.

\section{PENDAHULUAN}

Tanaman kelapa sawit (Elaeis guineensis Jacq.) merupakan komoditi pertanian yang mempunyai peran penting bagi subsektor perkebunan di Indonesia.
Menurut data Statistik Perkebunan Indonesia. Produksi kelapa sawit nasional dari tahun 2012 sampai tahun 2015 berturut-turut yaitu 26.015,518 ton; $27.782,004$ ton; $29.278,189$ ton; 
31.284,306 ton. Berdasarkan data Ditjen Perkebunan Kementrian Pertanian RI tahun 2016, Provinsi Riau, Sumatera Utara dan Sumatera Selatan merupakan provinsi pemberi kontribus besar penghasil CPO dari pulau Sumatera. Sedangkan Untuk pulau Kalimantan provinsi pemberi kontribusi terbesar pengasih CPO yaitu Kalimantan Tengah dan Kalimantan Barat. Kelima provinsi tersebut memiliki kontribusi sebesar $64 \%$ dari luas lahan perkebunan yang ada di Indonesia. Keberadaan perkebunan kelapa sawit ini mampu berkontribusi sebesar $71 \%$ terhadap produksi CPO nasional.

Provinsi Sumatera Barat tidak tercatat sebagai provinsi penghasil kelapa sawit terbesar di Indonesia. Dari 19 kabupaten/kota yang ada di Sumbar tercatat hanya 10 kabupaten dan 3 kota yang membudidayakan tanaman kelapa sawit., dengan produksi pada periode 2011-2014 yakni 354.445.70 ton; 1.841.580 ton; 426.476 ton; 450.941 ton dan 459.793 ton. Kabupaten penghasil kelapa sawit terbesar di Sumbar yakni Kabupaten Pasaman Barat dan Dharmasraya, dengan total produksi pada tahun 2015 yakni 246.992 ton dan 78.242 ton (BPS Sumbar, 2016).

Dharmasraya merupakan Kabupaten yang gencar membudidayakan tanaman kelapa sawit. Hal ini terlihat pada luas penggunaan lahan untuk sektor perkebunan mencapai 57,99 persen dari seluruh lahan pertanian. Bahkan pada tahun 2014 terjadi penambahan lahan perkebunan kelapa sawit sebesar 612,31 Ha (Statistik Dharmasraya 2017). Namun produksi kelapa sawit pada tahun 2014 justru menurun dari tahun 2013, sehingga produktivitas komoditas kelapa sawit pada tahun 2014 turun sekitar 3,93 persen. Berdasarkan survey yang dilakukan di lapangan dan data Dinas Pertanian Kab. Dharmasraya terungkap penyebab turunnya produksi kelapa sawit pada tahun 2014 adalah serangan hama dan penyakit. Serangan hama dan penyakit terutama terjadi di kecamatan sentra produksi di Kab. Dhamasraya salah satunya Kecamatan Timpeh.

Jenis hama yang sering menyerang hama kelapa sawit dilapangan adalah ulat api (Thosea asigna, Setora nitens, Darna trima, dan Thosea bisura), ulat kantung (Metisa plana dan Mahasena corbeti), tikus (Rattus sp.), kumbang (Oryctes rhinoceros), belalang (Valanga nigricornis). Berdasarkan data Direktorat Perlindungan Perkebunan diketahui total luas serangan hama pada tanaman kelapa sawit pada tahun 2014 yakni 78.764,31 ha. Tercatan hama dengan serangan terluas yakni ulat api dan tikus. Secara umum serangan hama dan penyakit dapat menurunkan produksi sampai $70 \%$ dan diwaktu yang bersamaan dengan serangan penyakit maka kerusakan bisa mencapai $100 \%$. Kerugian lain yang ditimbulkan adalah oleh serangan hama adalah bertambahnya biaya produksi yang harus dikeluarkan untuk memulihkan kondisi tanaman.

Pengendalian hama akan memberikan hasil yang optimal apabila terdapat informasi mengenai jenis, biologi dan ekologi hama yang akan dikendaikan. Informasi tersebut akan menjadi dasar untuk merakit metode pengendalian yang akan diaplikasikan. Pada saat ini informasi tentang jenis hama dan tingkat serangan pada kelapa sawit masih terbatas di Kab. Dharmasraya. Untuk itu perlu diakukan penelitian yang dapat menghasilkan data tentang jenis hama kelapa sawit di Kab. Dharmasraya.

\section{METODA PENELITIAN}

2.1. Penentuan Lokasi dan Tanaman Sampel 
Pengamatan hama dilakukan di perkebunan kelapa sawit rakyat Nagari Ranah Palabi, Taratak Tinggi, Timpeh, Tabek, dan Panyubarangan Kec. Timpeh Kab. Dharmasraya. Penelitian ini berbentuk survey lapangan. Lokasi penelitian ditentukan dengan metode Purposif Random Sampling. Kriteria pemilihan lokasi adalah kecamatan yang terdapat dikabupaten Dharmasraya dan penah dilaporkan terdapat serangan hama dalam kurun waktu lima tahun terakhir. Berdasarkan kriteria tersebut, ditetapkan lokasi penelitian di Kec. Timpeh. Pada Kecamatan yang sudah ditentukan dipilih sebanyak 5 Nagari yaitu Nagari Ranah Palabi, Taratak Tinggi, Timpeh, Tabek, dan Panyubarangan. Pada masing-masing Nagari dipilih sebanyak dua kebun kelapa sawit. Total kebun untuk pengamatan sebanyak 10 kebun. Luas kebun yang digunakan sebagai tempat pengambilan sampel \pm 1 ha, dengan umur tanaman 7 tahun.

\subsection{Pengambilan Sampel}

Pengambilan serangga contoh dilakukan dengan koleksi seranga hama secara langsung menggunakan tangan. Petak penelitian yang memiliki luas \pm 1 ha $( \pm 126$ tanaman) dipilih sebanyak $10 \%$ dari total tanaman yang ada yaitu 10 tanaman. Kemudian pada masingmasing tanaman sampel ditentukan pelepah yang akan diambil yaitu pada pelepah ke-15, 16 dan 17. Pelepah tersebut dipotong pada pangkal pelepah dan diturunkan menggunakan egrek. Koleksi serangga dilakukan dengan mengambil semua serangga pada pelepah yang telah dijatuhkan tersebut menggunakan pinset dan kuas. Koleksi juga dilakukan pada bagian tanaman lain yang menjadi tempat hidup hama. Serangga yang didapat kemudian dimasukkan ke dalam botol koleksi yang telah berisi alkohol $95 \%$.

\subsection{Sortasi dan Identifikasi Serangga Contoh}

Sortasi serangga contoh dilakukan dengan memisahkan serangga berdasarkan fungsionalnya. Serangga yang dinyatakan sebagai hama di identifikasi di Laboratorium Bioekologi Serangga, Fakultas Pertanian, Universitas Andalas. Identifikasi sampel didasarkan pada buku Panduan Pengenalan Serangga (Borror et al., 1992), buku Kunci Determinasi Serangga (Lilies, 1992) dan buku Hama dan Penyakit Kelapa Sawit (Agus, 2010).

\section{HASIL PENELITIAN DAN PEMBAHASAN}

\section{Deskripsi Lokasi Penelitian}

Penelitian dilakukan di lima nagari yakni Ranah Palabi, Taratak Tinggi, Timpeh, Tabek, dan Panyubarangan. Kebun kelapa sawit di masing-masing nagari memiliki karakterisitik yang berbeda, seperti varietas, jarak tanam, umur tanaman, pemupukan dan pengendalian OPT. Kebun di Nagari Ranah Palabi memiliki topograf datar, tanaman berumur 7 tahun. Kebun kelapa sawit di lokasi tersebut tidak dikelola secara intensif seperti pemupukan yang dilakukan sekali setahun dan gulma yang dibiarkan tumbuh tanpa pengendalian. Hal yang sama juga ditemukan di Nagari Tabek, petani tidak melakukan pemeliharaan secara intensif. Hal itu dapat dilihat dari sebagian besar kebun ditutupi oleh berbagai jenis gulma. 


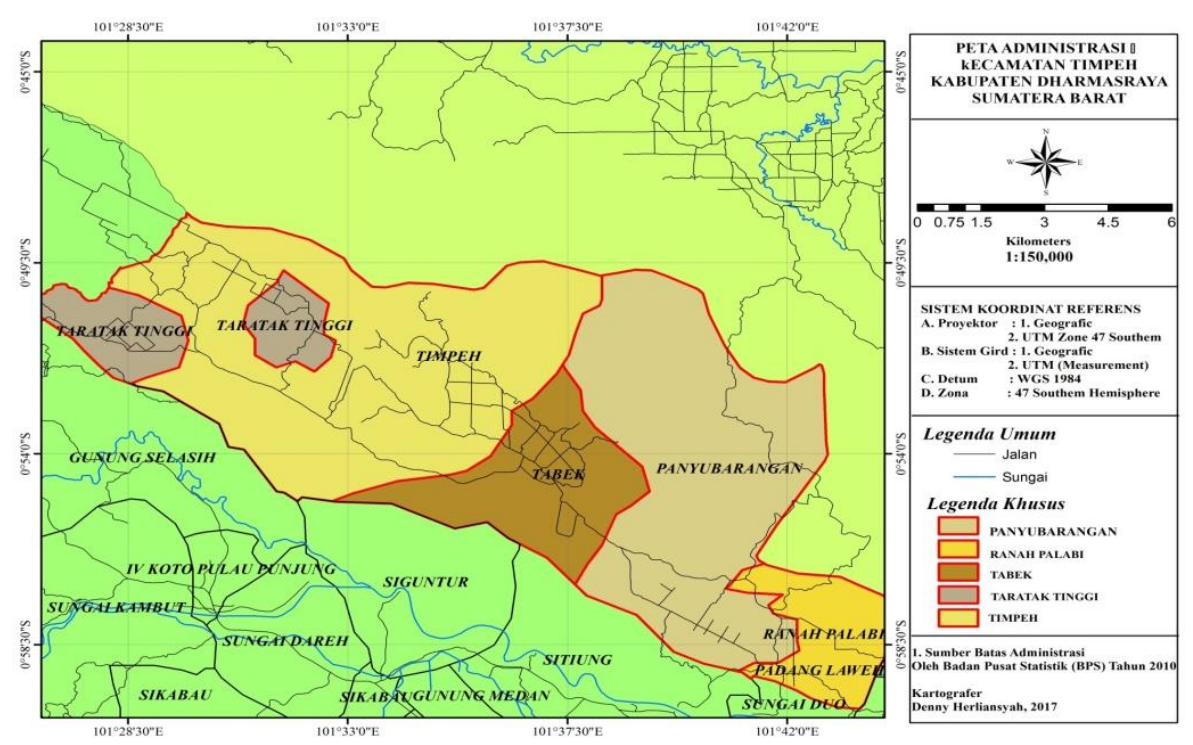

Gambar 1. Peta Administrasi Kecamatan Timpeh

Masing-masing Nagari di lokasi penelitian ini memiliki ketinggian serta kegiatan agronomis yang berbeda, Selengkapya dapat dilihat pada Tabel 1.

Tabel 1. Deskripsi Lokasi Penelitian

\begin{tabular}{|c|c|c|c|c|}
\hline Lokasi & Koordinat & $\begin{array}{c}\text { Ketinggian } \\
\text { Tempat }\end{array}$ & $\begin{array}{l}\text { Kegiatan } \\
\text { Agronomis }\end{array}$ & $\begin{array}{c}\text { Faktor } \\
\text { Lingkungan }\end{array}$ \\
\hline $\begin{array}{l}\text { Nagari Ranah } \\
\text { Palabi }\end{array}$ & $\begin{array}{l}\text { LS : } 00^{\circ} 65^{\prime} 59,2^{\prime \prime} \\
\text { BT: } 101^{\circ} 36^{\prime} 31,0^{\prime \prime}\end{array}$ & $115 \mathrm{~m} \mathrm{dpl}$ & $\begin{array}{l}\text { Umur tanaman } 6 \\
\text { tahun. } \\
\text { Jarak tanam } 9 \text { x } 9 \\
\text { meter. } \\
\text { Pengendaliah OPT } \\
3 \text { bulan sekali. } \\
\text { Varietas yang di } \\
\text { Budidayakan } \\
\text { Simalungun. }\end{array}$ & $\begin{array}{l}\text { SH: } 30^{\circ} \mathrm{C} \\
\text { KL: } 70 \% \\
\text { IC: } 1306\end{array}$ \\
\hline $\begin{array}{l}\text { Nagari Taratak } \\
\text { Tinggi }\end{array}$ & $\begin{array}{l}\text { LS : } 00^{\circ} 97^{\prime} 21,4{ }^{\prime \prime} \\
\text { BT:101 } 69 ' 59,9 ”\end{array}$ & $95 \mathrm{~m} \mathrm{dpl}$ & $\begin{array}{l}\text { Umur tanaman } 8 \\
\text { tahun. } \\
\text { Jarak tanam } 9 \text { x } 9 \\
\text { meter. } \\
\text { Pengendalian } \\
\text { ketika terserang. } \\
\text { Varietas yang di } \\
\text { Budidayakan } \\
\text { Simalungun. }\end{array}$ & $\begin{array}{l}\text { SH: } 27^{\circ} \mathrm{C} \\
\text { KL: } 69 \% \\
\text { IC: } 1196\end{array}$ \\
\hline
\end{tabular}




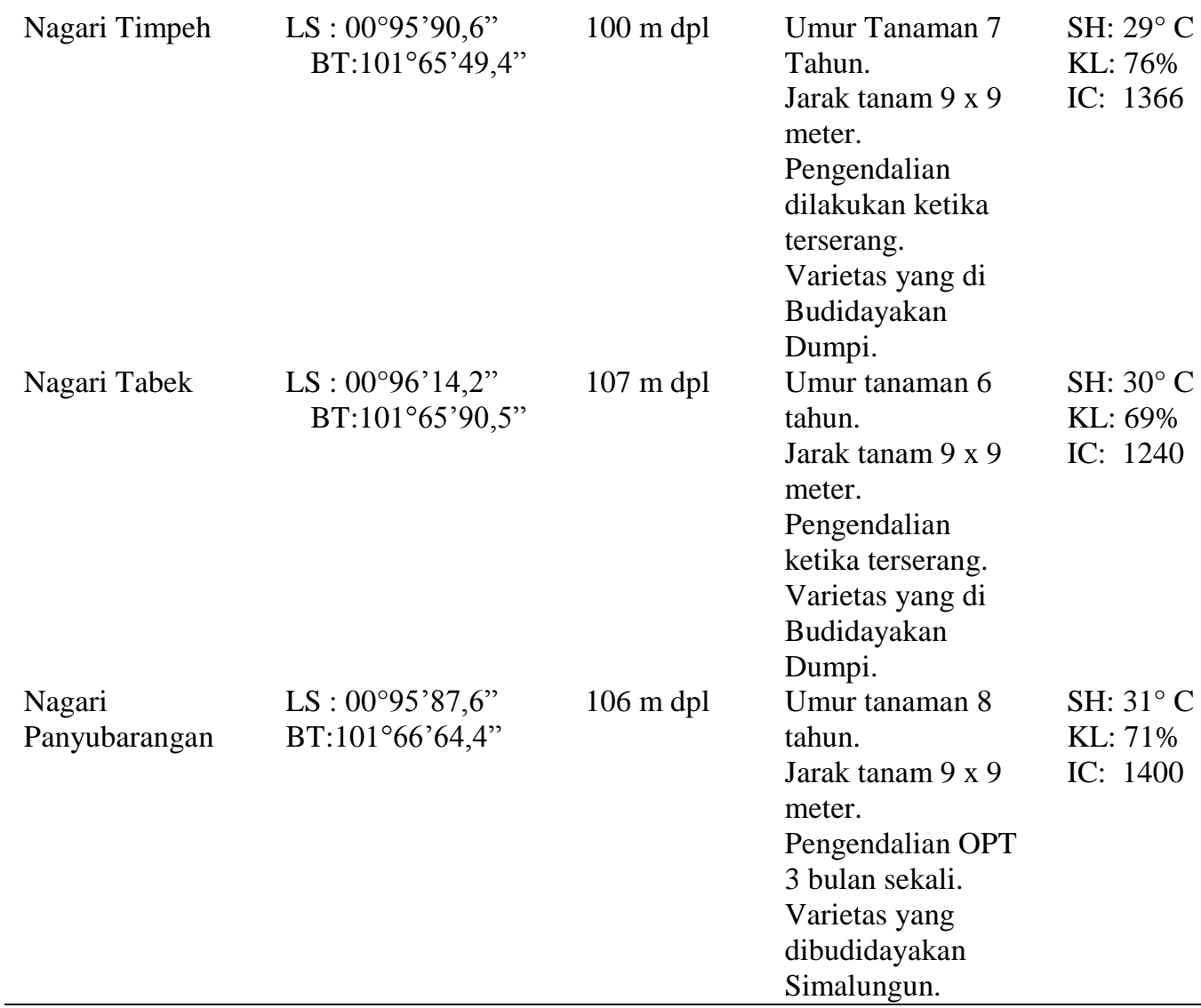

*Keterangan: $\mathrm{SH}=\mathrm{Suhu}, \mathrm{KL}=$ Kelembaban, $\mathrm{IC}=$ Intensitas Cahaya

$\begin{array}{lrr}\text { Berdasarkan } & \text { Tabel 1 } & \text { diketahui } \\ \text { bahwa kelima } & \text { Nagari } & \text { tempat } \\ \text { dilakukannya pengambilan } & \text { sampel }\end{array}$
memiliki titik koordinat yang relatif berbeda dengan ketinggian berkisar antara $95 \mathrm{~m}$ dpl sampai $115 \mathrm{~m} \mathrm{dpl}$. Lokasi tertinggi yakni Nagari Ranah Palabi sedangkan lokasi yang terendah yakni pada Nagari Taratak Tinggi. Untuk faktor lingkungan di masing-masing Nagari ini berbeda, kebun di Nagari Taratak Tinggi dan Timpeh saat dilakukannnya pengambilan sampel memiliki suhu yang relatif lebih rendah yaitu $27^{\circ} \mathrm{C}$ dan $29^{\circ} \mathrm{C}$.

Kebun di Nagari Ranah Palabi memiliki topografi yang cenderung datar dengan umur tanaman 6 tahun memiliki jarak tanam rata-rata $9 \times 9$ meter. Petani melakukan pengendalian OPT 3 bulan sekali. Sedangkan untuk Kebun Nagari Tabek memiliki topografi datar dengan umur tanaman 6 tahun. Jarak tanaman $9 \mathrm{x}$ 9 meter. Pengendalian hama dan penyakit di kebun ini dilakukan hanya ketika terjadi serangan.

Topografi kebun kelapa sawit di Nagari Panyubarangan berbukit dengan umur tanaman 8 tahun. Pada tahun 2017, kebun tersebut terserang ulat api dengan total luas serangan yakni \pm 60 ha intensitas serangan tergolong berat (Dinas Pertanian Kabupaten Dharmasraya).

Topografi kebun kelapa sawit di Nagari Timpeh yakni berbukit dan diselingi rawa dengan umur tanaman 7 tahun.. Total luas lahan yakni 2 ha. Kebun kelapa sawit di Nagari ini dipelihara dengan pemupukan 3 bulan sekali dan pengendalian gulma secara kontinu. Sedangkan untuk pengendalian hama dan penyakit dilakukan ketika terserang. Hal yang sama juga ditemukan di kebun Nagari Taratak Tinggi dengan 
topografi datar dan umur tanaman 8 tahun. Kebun di Nagari ini tidak ditumbuhi gulma.

\section{Komunitas Serangga Hama Pada Sawit Di Kecamatan Timpeh}

Berdasarkan pengamatan yang dilakukan ditemukan sebanyak 353 individu serangga hama yang tergolong ke dalam 4 ordo, 9 famili dan 15 spesies. Selengkapnya dapat dilihat pada Tabel 2. Semua serangga tersebut tergolong hama pada tanaman kelapa sawit

Tabel 2. Kelimpahan Serangga Hama Kelapa Sawit di Kecamatan Timpeh

\begin{tabular}{lllcc}
\hline \multicolumn{1}{c}{ Ordo } & \multicolumn{1}{c}{ Famili } & \multicolumn{1}{c}{ Genus/Spesies } & $\begin{array}{c}\text { Jumlah } \\
\text { Individu }\end{array}$ & KR \\
\hline Coleoptera & Chrysomelidae & Plessispa sp. & 4 & 1.12 \\
& Scarabaeidae & Adoretus compressus & 3 & 0.84 \\
Isoptera & Rhinotermitidae & Coptotermes sp. & 247 & 69.18 \\
Lepidoptera & Erebidae & Ambadra rafflesi & 3 & 0.84 \\
& & Calliteara horsfieldii. & 4 & 1.12 \\
& & Dasychira inclusa & 2 & 0.56 \\
& Limacodidae & Darna trima & 2 & 0.56 \\
& & Setora nitens & 1 & 0.28 \\
& Saturnidae & Saturnidae sp. & 31 & 8.68 \\
& Psychidae & Mahasena corbetti Tams. & 17 & 4.76 \\
& Acrididae & Melanoplus & 8 & 2.24 \\
& & Valanga & 15 & 4.20 \\
& Grylludae & Gryllus sp. & 12 & 3.36 \\
& Tettigoniidae & Scudderia & 2 & 0.56 \\
\hline
\end{tabular}

Berdasarkan Tabel 2 diketahui bahwa hama yang banyak dikoleksi berasal dari ordo Lepidoptera yakni 4 famili tersebut adalah Erebidae, Limacodidae, Saturnidae dan Psychidae. Sutrisno (2010) melaporkan bahwa $90 \%$ dari ordo Lepidoptera merupakan serangga ngengat sedangkan sisanya adalah kupu-kupu. Menurut Borror et al. (1992) ordo tersebut yaitu lepidoptera merupakan jenis serangga pengunyah dan penghisap yang merupakan hama pada tanaman budidaya. Sutrisno (2010) menjelaskan Ngengat dan kupu-kupu termasuk kedalam ordo lepidoptera dimana $90 \%$ merupakan serangga ngengat sedangkan sisanya adalah kupukupu. Kelompok ngengat family Erebidae
(Lepidoptera: Noctuoidea) di Indonesia tersebar di Kawasan tropis dan terdiri dari 18 sub family.

Spesies hama yang memiliki jumlah individu tertinggi yaitu Coptotermes sp dari famili Rhinotermitidae ordo isoptera sebanyak 247 individu. Hal yg sama dilaporkan Arnita (2017) bahwa serangga hama kelapa sawit dan individu yang paling tinggi yakni Coptotermes sp yaitu sebanyak 178 individu. Coptotermes sp ditemukan banyak di lapangan karena bersifat sosial yang hidup berkoloni. Aditia (2015) menyatakan bahwa Genus Coptotermes sp termasuk dalam kelompok rayap yang merupakan salah satu jenis serangga dari Ordo Isoptera. 
Serangga hama yang paling sedikit dikoleksi berasal dari ordo Lepidoptera famili Limacodidae spesies $S$. nitens yaitu sebanyak 1 individu. Sedikitnya jumlah individu spesies ini ditemukan disebabkan siklus hidup s. nitens yang singkat menyebabkan hanya sedikit yang dapat dikoleksi. Hartley (1979) menjelaskan bahwasanya $S$. nitens memiliki siklus hidup yang lebih singkat dibandingkan ulat api jenis lainnya yaitu 42 hari. Hal lain yang mempengaruhi spesies ini hanya sedikit yang ditemukan yakni berkurangnya sumber makanan yang ada dikarenakan sebagian besar daun tanaman sudah habis dan tersisa lidi.

\section{Sebaran Hama Kelapa Sawit Dibeberapa Lokasi Penelitian.}

Berdasarkan pengamatan yang dilakukan dapat diketahui bahwa hama kelapa sawit di masing-masing Nagari tidak merata. Hanya satu spesies yang menyebar merata di semua Nagari. Sedangan spesies lain hanya terdapat di Nagari tertentu saja. Selengkapnya dapat dilihat pada Tabel 3 .

Tabel 3. Sebaran Kelimpahan Hama Kelapa Sawit

\begin{tabular}{lccccc}
\hline \multirow{2}{*}{ Genus/Spesies } & \multicolumn{4}{c}{ Lokasi Penelitian (Nagari) } \\
\cline { 2 - 6 } & $\begin{array}{c}\text { Panyubara } \\
\text { ngan }\end{array}$ & $\begin{array}{c}\text { Ranah } \\
\text { Palabi }\end{array}$ & $\begin{array}{c}\text { Taratak } \\
\text { Tinggi }\end{array}$ & Tabek & Timpeh \\
\hline Plessispa sp. & 2 & 0 & 0 & 2 & 0 \\
Adoretus compressus & 0 & 0 & 0 & 3 & 0 \\
Coptotermes sp. & 30 & 0 & 141 & 0 & 76 \\
Ambadra rafflesi & 1 & 0 & 0 & 0 & 2 \\
Calliteara horsfieldii. & 2 & 0 & 1 & 1 & 0 \\
Dasychira inclusa & 0 & 0 & 0 & 0 & 2 \\
Darna trima & 2 & 0 & 0 & 0 & 0 \\
Setora nitens & 0 & 0 & 1 & 0 & 0 \\
Saturnidae sp. & 0 & 4 & 9 & 10 & 5 \\
Mahasena corbetti Tams. & 3 & 2 & 3 & 4 & 5 \\
Melanoplus sp. & 3 & 2 & 0 & 2 & 1 \\
Valanga sp. & 0 & 5 & 5 & 0 & 5 \\
Gryllus sp. & 3 & 0 & 0 & 6 & 15 \\
Scudderia sp. & 0 & 0 & 0 & 0 & 1 \\
\hline
\end{tabular}

Spesies hama dengan sebaran terluas yakni Mahesa corbetti Tams karena ditemukan di seluruh lokasi penelitian. Hama tersebut ditemukan di Nagari Panyubarangan sebanyak 3 individu, Ranah Palabi sebanyak 2 individu, Taratak Tinggi sebanyak 3 individu, Tabek sebanyak 4 individu, dan Nagari Timpeh sebanyak 5 individu. $M$. corbetti Tams merupakan salah satu hama utama tanaman kelapa sawit. Itulah penyebab spesies ini di temukan di seluruh lokasi penelitian. Selain itu, pergerakan nya yang terbatas membuat spesies ini mudah ditemukan di semua
Nagari. Berbeda dengan spesies lain, ketika dilakukannya koleksi dapat berpindah-pindah maupun bersembunyi. Selain itu, spesies ini merupakan hama

Terdapat 5 spesies hama yang hanya ditemukan di satu lokasi penelitian yakni Adoretus compressus di Nagari Tabek, Dasychira inclusa di Nagari Timpeh, Darna Trima di Nagari Panyubarangan, Setora nitens di Nagari Taratak Tinggi dan Scudderia sp. di Nagari Timpeh. Ketersediann makanan dan vegetasi menjadi beberapa penyebab spesies ini hanya terdapat di Nagari tertentu saja. 


\section{Deskripsi Serangga Hama pada Tanaman Kelapa Sawit}

\section{Plessispas sp.}

Plessispas sp. merupakan serangga

hama kelapa sawit dari famili Chrysomelidae. Spesies ini ditemukan di Nagari Tabek dan Nagari Panyubarangan. Total jumlah individu yang ditemukan sebanyak 4 individu. Stadium yang ditemukan di lapangan yakni fase imago. Fase merugikan dari hama ini adalah stadium larva. Larva menyerang pucuk tanaman dengan gejala pucuk menjadi rusak, kemerahan dan mengering.

\section{Adoretus compressus}

A. compressus merupakan serangga hama kelapa sawit dari famili Scarabaeidae. Spesies ini ditemukan di Nagari Tabek sebanyak 3 individu. Spesies ini ditemukan pada bagian daun dan disela-sela pelepah kelapa sawit. Spesies ini memakan sebagian daging daun bagian tengah. Serangan dari kumbang ini menyebabkan daun tanaman berlobang pada bagian tengahnya.

\section{Coptotermes sp.}

Coptotermes sp ditemukan di Nagari Panyubarangan, Taratak Tinggi dan Nagari Timpeh. Total individu yang ditemukan sebanyak 247 individu. Spesies jenis ini ditemukan berkoloni pada tanaman yang berumur 8 tahun. Spesies ini menyerang tanaman pada bagian batang, terbukti saat dilakukannya pengambilan sampel hama ini ditemukan di batang sedang menggerogoti batang tersebut. Gejala serangan rayap berupa terdapat lorong-lorong tanah berukuran kecil di permukaan batang

\section{Ambadra rafflesi.}

A. rafflesi merupakan salah satu jenis ulat bulu yang menyerang kelapa sawit. A. rafflesi ditemukan di Nagari Timpeh dan Panyubarangan. Total individu yang ditemukan yakni sebanyak 3 individu. Spesies hama ini memakan daun tanaman pada bagian bawah daun.
Kerusakan yang ditimbulkan hama ini berupa daun tanaman yang berlobang.

\section{Calliteara horsfieldii.}

C. horsfieldii merupakan salah satu hama dari family erebidae. C. horsfieldii ditemukan di Nagari Panyubarangan, Tabek dan Taratak Tinggi. Total individu yang ditemukan sebanyak 4 individu. Spesies ini menyerang tanaman dengan memakan daun bagian bawah. Kerusakan yang ditimbulkan spesies ini berupa daun tanaman yang berlobang.

6. Dasychira inclusa.

D. inclusa merupakan salah satu hama tanaman kelapa sawit belum menghasilkan. Pada lahan penelitian spesies ini ditemukan pada tanaman menghasilkan di Nagari Timpeh. Total individu yang ditemukan sebanyak 2 individu. Kerusakan yang ditimbulkan spesies ini berupa daun tanaman yang berlobang.

\section{Darna Trima}

D. trima merupakan salah satu jenis ulat api. Spesies ini ditemukan sebanyak di Nagari Panyubarangan. Total individu yang ditemukan sebanyak 2 individu. Hama ini ditemukan pada daun tanaman yang masih muda. Kerusakan yang ditimbulkan hama ini berupa daun yang berlubang-lubang. Spesies ini ditemukan pada lahan yang sebelumnya terjadi ledakan ulat api. Dibawah pohon tanaman sendiri terdapat banyak pupa yang sudah membusuk.

\section{Setora niten}

Spesies ini merupakan salah satu jenis ulat api. Spesies ini ditemukan di Nagari Taratak Tinggi.Total individu yang ditemukan yakni sebanyak 1 individu. Saat ditemukan larva hama ini sedang memakan daun ke 16, disekitar larvanya daun berwarna hitam seperti hangus terbakar. Sedangkan bagian bawah daun habis dan tersisa lidinya saja. 9. Saturnidae sp.

Ulat ini merupakan salah satu jenis ulat bulu yang paling banyak ditemukan. 
Spesies ini ditemukan di Nagari Ranah Palabi, Taratak Tinggi dan Tabek. Total individu yang ditemukan sebanyak 35 individu. Hama ini ditemukan pada daun bagian bawah. Kerusakan yang ditimbulkan oleh spesies ini daunnya berlobang pada pinggir dan tengah daun 10. Mahesa corbetti

M.corbetti merupakan salah satu jenis ulat kantung yang menyerang tanaman dalam semua tingkat umur. Spesies ini ditemukan di Nagari Tabek, Timpeh, Ranah Palabi, Taratak Tinggi dan Panyubarangan. Total individu yang ditemukan sebanyak 17 individu. Larva ditemukan sedang bergantung di pangkal pelepah dan bagian bawah daun.

11. Melanoplus sp.

Serangga hama ini ditemukan di Nagari Ranah Palabi, Timpeh, Tabek dan panyubarangan. Total individu yang ditemukan yakni sebanyak sebanyak 8 individu. Hama ini ditemukan sedang beterbangan di sekitaran tanaman atau sedang di daun. Kerusakan yang diakibatkan spesies ini berupa daun tersobek dan berlobang.

13. Valanga sp.

Serangga hama ini ditemukan di Nagari Ranah Palabi, Timpeh, Tabek dan Panyubarangan. Total individu yang ditemukan sebanyak 15 individu. Spesies ini ditemukan hinggap di daun atau pelepah tanaman. Gejala serangan dari belalang berupa daun yang berlobang.

14. Gryllus sp.

Gryllus sp ditemukan di Nagari Timpeh, Tabek dan Panyubarangan. Total individu yang ditemukan sebanyak 24 individu. Pada saat dilakukan pengambilan sampel, hama ini ditemukan di tanah sekitar gawangan.

15. Scudderia sp.

Spesies ini ditemukan di Nagari Timpeh dan Tabek. Total individu yang ditemukan yakni sebanyak 2 individu. Spesies ini ditemukan pada daun tanaman. Spesies ini menyerang bagian akar tanaman atau bagian yang ada dibawah tanah.

\section{KESIMPULAN}

Terdapat 357 individu yang dinyatakan sebagai hama yang tergolong kedalam 4 ordo, 9 famili dan 15 spesies. Spesies tersebut yakni Plessispa sp, Adoretus Compressus, Coptotermes sp, Ambadra rafflesi, Calliteara Horsfieldii, Dasychira Inclusa, Darna trima, Setora Nitens, Saturnidae sp, Mahasena corbetti Tams., Melanoplus sp, Valanga sp, Gryllus sp, dan Scudderia sp. Jumlah individu tertinggi yang ditemukan yakni Coptotermes sp dan yang paling rendah yakni dari spesies Setora nitens.

\section{DAFTAR PUSTAKA}

Basri, M.W., K. Norman., dan Hamdan. (1995). Natural enemies of the bagworm, Metisa plana (Lepidoptera: Psychidae) and their impact on host population regulation. Crop Prot. 14(8): 637645.

Basri, M.W., dan Kevan. (1995). Life History and Feeding Behaviour of the Oil Palm Bagworm M. plana Walker (Lepidoptera: Psychidae). Elaeis journal 9 (2): 82-101.

Badan Pusat Statistik. (2016). Produksi Kelapa Sawit Perkebunan Rakyat 2007-2015. Padang: Sumatera Barat.

Badan Pusat Statistik Dharmasraya. (2015). Dharmasraya Dalam Angka. Pulau Punjung: Dharmasraya.

Borror, D.J., C.A Triplehorn., N.F.Johnson., (1992). Pengenalan 
Pelajaran Serangga. Ed ke-6. Gadjah Mada University Press. Yogyakarta.

Direktorat Jendral Perkebunan. 2016. Statistik Perkebunan Indonesia Komoditas Kelapa Sawit 2014$2016 . \quad$ Available: http://ditjenbun.pertanian.go.id. [Diakses tanggal 04 Mei 2017].

Lilies, S.C. (1992). Kunci Determinasi Serangga. Jakarta: Kanisius.

Norman K., Robinson., dan Basri. (1995). Common Bagworm Pests (Lepidoptera: Psychidae) Of Oil Palm in Malaysia with notes on related South-east asian species. Malayan nature journal (49): 93123.

Pusat data dan Informasi Pertanian. (2015). Statistik Iklim, Organisme Pengganggu Tanaman dan Dampak Perubahan Iklim 2012-2015. Kementerian Pertanian. Jakarta.
Sudharto, P.S., Z.A Aini., C.U Ginting., dan B. Papierok. (1998). Perkembangan Jamur Cordceps aff. militaris pada dedak padi dan patogenisitasnya terhadap kepompong Sethotosea asigna van Eecke. Jurnal Penelitan Kelapa Sawit. 1998. 6920: 141-151.

Susanto, (2005). Pengurangan Populasi Larva Oryctes rhinoceros pada system lubang tanam besar. Jurnal Penelitian Kelapa Sawit. 14(1):2-3.

Syed, R.A and Sankaran, T. (1972). The Natural Enemies of Bagworns on Oil Palm in Sabah, East Malaysia. Pasific Insects 14 (1):57-71. 